\title{
Root growth and carbohydrate partitioning in cotton subjected to shading in the initial phase
}

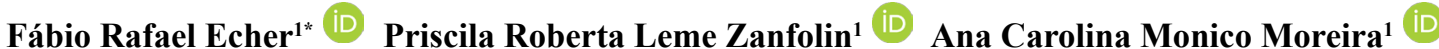 \\ Ana Cláudia Pacheco Santos ${ }^{1}$ (D) Pedro Henrique Gorni ${ }^{1}$ (D)
}

${ }^{1}$ Departamento de Agronomia, Universidade do Oeste Paulista (UNOESTE), 19067.175, Presidente Prudente, SP, Brasil. E-mail: fabioecher@unoeste.br. ${ }^{*}$ Corresponding author

\begin{abstract}
Cotton cultivation in Brazil tends to occur mostly in the rainy season, and at the time of developing the crop there are often prolonged periods of low solar radiation. The objective of this work was to evaluate the root development of cotton cultivars subjected to shading in the initial phase. The experiment was carried out in a greenhouse, using rhizotrons. The experimental design was a $2 x 2$ factorial in randomized blocks with five replications. The treatments were composed of cotton cultivars TMG 1 WS (early) and TMG 8 WS (late) and luminosity conditions: non-shaded and shaded (50\% reduction of luminosity). There were no interactions between the factors "shading" and "cultivars" for any parameter evaluated. Shading reduced total and lateral root growth from the 21 days after emergence (DAE) and the main root at 24DAE. Shading caused reductions in length (60\%), surface (65\%), mean diameter (15\%), root volume (69\%), root dry matter mass (83\%) and shoot (64\%), as well as decreasing the content (36\%) and the accumulation of carbohydrates in the shoot (73\%). Shading at early cotton development reduces the shoot carbohydrates production, affecting dry matter accumulation and root growth, and this response is independent of the cultivar.
\end{abstract}

Key words: root length, dry weight, radiation.

Crescimento radicular e partição de carboidratos em algodoeiro submetido ao sombreamento na fase inicial

RESUMO: $O$ cultivo do algodoeiro no Brasil está concentrado no período chuvoso, e no momento do estabelecimento da lavoura frequentemente há periodos prolongados de baixa radiação solar. O objetivo deste trabalho foi avaliar o desenvolvimento radicular de cultivares de algodoeiro submetidos ao sombreamento na fase inicial da cultura. O experimento foi realizado em ambiente controlado, em rizotrons. O delineamento experimental foi um fatorial $2 \times 2 \mathrm{em}$ blocos ao acaso com cinco repetições. Os tratamentos foram as cultivares de algodão TMG $11 \mathrm{WS}$ (precoce) e TMG $81 \mathrm{WS}$ (tardia) e as condições de sombra: sem sombra e com sombra (50\% de redução da luminosidade). Não houve interação entre os fatores "sombra" $e$ "cultivares estudadas" para nenhum parâmetro avaliado. A sombra reduziu o crescimento radicular total e das raizes laterais a partir dos 21 dias de emergência (DAE) e da raiz principal aos 24DAE. O sombreamento reduziu o comprimento (60\%), a superficie (65\%), o diametro médio (15\%), o comprimento por volume (60\%), o volume radicular (69\%), a massa de matéria de seca da raiz (83\%) e da parte aérea (64\%), o teor (36\%) e o acúmulo de carboidratos na parte aérea (73\%). Em conclusão, o sombreamento na fase inicial de desenvolvimento do algodoeiro reduz a produção de carboidratos da parte aérea, afetando o acúmulo de matéria seca e o crescimento radicular, sendo que essa resposta independe da cultivar.

Palavras-chave: comprimento da raiz, peso seco, radiação.

\section{INTRODUCTION}

Cotton (Gossypium hirsutum L.) is produced around the world in a variety of environments, including tropical and subtropical regions. Therefore, most of the production areas are under tropical savannah climate (Aw - Köppen), as in central Brazil and south - central India. In India, $43 \%$ of the cotton area (5.1 million ha) occurs in states under the influence of this climate, and 2/3 of the area are dependent on monsoon rains.

In Mato Grosso, rainfed cotton is sown as a second crop following soybean around January. Radiation is reduced in the rainy season because of cloudness. After the end of the rainy season, the moisture stored in the soil subsurface would be the main source of water for the plants, and those with a shorter root system would enter into stress earlier. Light is one of the main factors affecting growth and development of plants, since it provides energy for photosynthesis and consequently for the production of carbohydrates. In response to light, several molecules and metabolites, such as phytohormones, sucrose, RNA's and proteins, are produced in the aerial part and mobilized at the roots, where they trigger photomorphogenic changes, such as root growth and lateral root emission (LEE et al., 2017). Previous studies have shown the negative effect of reduced radiation availability on flowering and boll development periods on yield and fiber 
quality (ZHAO \& OOSTERHUIS, 1998; ECHER \& ROSOLEM, 2015). However, there is a lack of information on the effect of light reduction during initial cotton development, especially in relation to root system development.

ALAMEDA et al. (2012) reported a reduction in the length and root diameter of tobacco plants subjected to shading. BRAND et al. (2016) reported that the combination of low temperature with a high $\mathrm{CO}_{2}$ concentration and UV-B, up to 14 days after emergence reduced the root length by $42 \%$ in relation to the control, possibly due to the effect of these factors on the photosynthetic activity of the plant. However, studies on the effect of light reduction on root growth in the early cotton stages are scarce. In view of the above, the objective of this work was to evaluate the cotton root growth as affected by shading at early stage of development, and to verify if different cultivars could present varied responses to the lowest light incidence.

\section{MATERIAL AND METHODS}

The experiment was conducted in a greenhouse, located at latitude $22^{\circ} 07^{\prime} 04^{\prime}$ ' S, longitude $51^{\circ} 22^{\prime} 04^{\prime \prime} \mathrm{W}$ and at $432 \mathrm{~m}$ altitude, at Universidade do Oeste Paulista (UNOESTE), Presidente Prudente, São Paulo, Brazil. The climatic variables; such as radiation and maximum and minimum temperatures during the experiment are presented in figure 1.
The experimental design was a randomized block design in a $2 \times 2$ factorial scheme, using early (TMG $11 \mathrm{WS}$ - former FMT 523 - genitors FM 966xCCA 347) and late (TMG 81WS - former FMT 701 genitors DeltaOpal x IAC 22) maturity types of cotton cultivars and presence and absence of shading conditions, with 5 replicates. The shading was performed using a black screen with $50 \%$ reduction of radiation, implanted at the time of emergence of the seedlings and maintained until 27 days after emergence (DAE). The shading cloth was placed at a distance of $50 \mathrm{~cm}$ from the plants, supported by a metal wire rod.

Cotton plants were grown in rizotrons (experimental unit) filled with commercial substrate (pH: 7; organic matter: $60 \mathrm{~g} \mathrm{dm}^{-3}$; $\mathrm{P}, \mathrm{S}_{-} \mathrm{SO}_{4}{ }^{2-}, \mathrm{B}$ and $\mathrm{Zn}$ of $656,348,0,9$ and $0,16 \mathrm{mg} \mathrm{dm}^{-3}$, respectively; $\mathrm{K}, \mathrm{Ca}, \mathrm{Mg}$ and CTC of 16, 218, 49 and $295 \mathrm{mmol}_{\text {c }}$ $\mathrm{dm}^{-3}$, respectively; Base saturation: $97 \%$ )

The rhizotrons consisted of PVC pipes with a diameter of $0,30 \mathrm{~m}$ and a height of $0,80 \mathrm{~m}$ and a volume of $0.028 \mathrm{~m}^{3}$. The tubes were cut in the middle in the longitudinal direction, forming a flat face, in which a glass wall (rizotron) was installed to provide the visual accompaniment of the root growth of the plants. On the glass wall a sliding cover of laminated wood was added, to avoid the incidence of light, and inhibition of root growth. The tubes were tilted to 15 degrees, to allow the growth of the root system parallel to the glass.

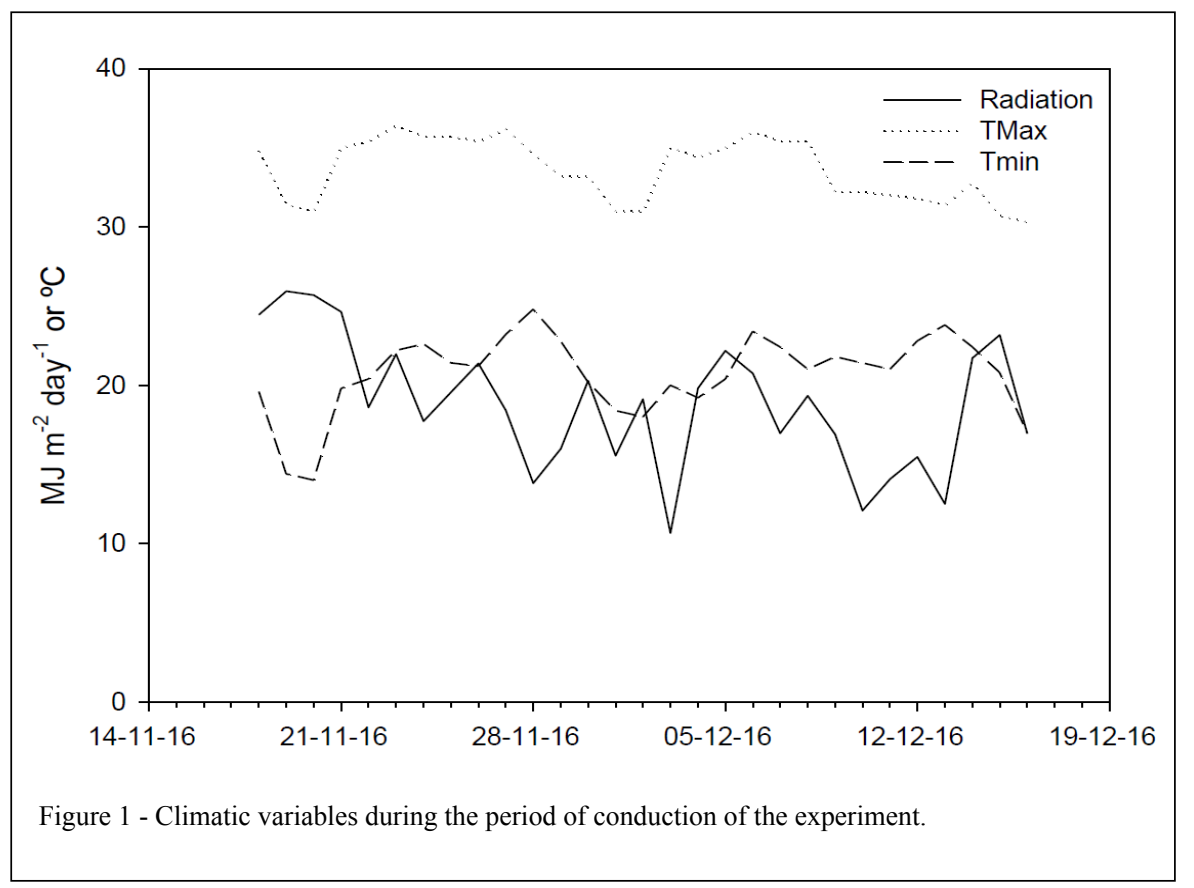

Ciência Rural, v.49, n.1, 2019. 
The plants were irrigated daily, maintaining soil moisture near the field capacity.

Five seeds were sown per experimental unit at a depth of $2 \mathrm{~cm}$ and two days after emergence a thinning was performed, leaving only two seedlings per rizotron. The plants were conducted until the root system reached $80 \mathrm{~cm}$ depth of rizotron, which occurred at 27 DAE on unshaded control treatments. Biometric assessments of plant height was performed at 7, 14, 21 and 24 DAE. The evaluation of the root system was performed by marking the roots that grew next to the glass, using plastic film and colored pens at 7, 9, 12, 19, 21, 24 and 27 DAE. The marked plastic films were superimposed on a checkered sheet $(0.5 \times 0.5 \mathrm{~cm})$, where the intersections of the roots with the lines were counted, following the methodology of TENNANT (1975), according to the formula: L $=\mathrm{Nx} 14 / 16$, where: $\mathrm{L}$ is the root length and $\mathrm{N}$ is the number of intersections. On the last day of evaluation of the root growth (27 DAE) the plants were cut at the height of the colon, separating shoot and root. After removal of the aerial part of the plants, the soil was removed from the rhizotrons and passed through $2 \mathrm{~mm}$ mesh sieves, with the aid of water jets, to separate the roots of the cotton plant from the soil.

Root morphology such as length, surface, mean diameter, volume and length in each diameter class were evaluated by scanning the roots in Winrhizo software. After that, the roots and aerial part were dried in a forced aeration oven at $65^{\circ} \mathrm{C}$ for 48 hours and weighed in a semi-analytical balance for dry mass determinations. The content and accumulation of total carbohydrates in shoot and roots were determined according to DUBOIS et al. (1956). A two (shading $\mathrm{x}$ cultivar) and three-way (shading $\mathrm{x}$ cultivar $\mathrm{x}$ DAE) ANOVA and regression (for plant height and root length) were performed and the mean values were compared using LSD test $(p<0.05)$ using the SISVAR statistical program (FERREIRA, 2011).

\section{RESULTS}

Plant height was not affected by treatments (cultivars and shading) (Table 1) and increased linearly with time (Figure 2). There were no interactions between the cultivars and the shade regime on cotton root growth (Table 1). However, shading reduced both main root length at 24 and 27DAE, lateral root length and total length at 21 , 24 and 27DAE (Table 1, Figure 3). Up to 18DAE, shaded and non-shaded plants presented similar performance, but after 21 DAE the non-shaded plants presented increasing linear growth for main root length, lateral roots and consequently for total root length; while the shaded plants showed polynomial a less vigorous (Figure 3 ).

There were no interactions between the shading factors and cultivars, nor was there any interference of the cultivar on root characteristics such as length, surface, mean diameter, length by volume, root volume (Table 2) and length by diameter class (Table 3). On the other hand, shading reduced the length $(-60 \%)$, surface $(-65 \%)$, mean diameter $(-15 \%)$, length by volume $(-60 \%)$ and root volume $(-69 \%)$ compared to the treatment without shading (Table 2). Both the dry weight and the carbohydrate accumulation in the root and shoot were not affected by the interaction between the study factors "shading" and "cultivars" (Table 4). There was also no isolated effect for the "cultivar" factor in relation to these variables. However, shading reduced root (83\%) and shoot dry weight $(64 \%)$, as well as reducing the concentration $(36 \%)$ and the accumulation of carbohydrates in the shoot $(73 \%)$. Although the shading had no effect on the carbohydrate content in the roots, there was a distinct decrease in the accumulation of carbohydrates in the roots of the cotton, when the plants were subjected to shading, this occurred due to the drastic reduction of root dry weight (Table 4).

\section{DISCUSSION}

The height of the plant was not affected by the shading in the initial stage of development of the crop, and this may be related to the fact that, although there is less production of carbohydrates and dry matter, there is an increase in the plant etiolation when its growth occurs under certain conditions. ZHAO \& OOSHERTUIS (2000) did not observe effect of shading on the height of the cotton in the stages of floral bud, beginning and end of flowering and development of the fruits. Thus, the present study corroborates previous studies in which it is stated that shading tends to have no effect on plant height.

On the other hand, shade reduced root growth at $21 \mathrm{DAE}$, although already at $12 \mathrm{DAE}$ the curves presented a differentiated pattern of growth as a consequence of the reduction of cotyledonary reserves. Therefore, from $12 \mathrm{DAE}$ shading reduced the production of carbohydrates and consequently their translocation to the root system, affecting root growth. Similar results were obtained by HANLEY et al. (2004) in sunflower and pea, where the peak of the seedling growth rate occurred at 10.3 and 10.8 DAE, respectively, suggesting that this would be 
Table 1 - The P-values for sources of variation ant their interactions for root length and plant height.

\begin{tabular}{lcccc}
\hline & Tap root length & Lateral root length & Total root length & Plant height \\
\hline Cultivar (C) & 0.22 & 0.90 & 0.59 & 0.38 \\
Shading (S) & 0.01 & 0.000 & 0.000 & 0.11 \\
DAE (D) & 0.000 & 0.000 & 0.000 & 0.000 \\
C x S & 0,49 & 0.13 & 0.31 & 0.30 \\
C x D & 0.62 & 0.64 & 0.56 & 0.91 \\
S x D & 0.001 & 0.005 & 0.006 & 0.45 \\
C x S x D & 0.23 & 0.33 & 21.82 & 0.96 \\
CV\% & 28.98 & 25.99 & 15.81 \\
\hline
\end{tabular}

the end of the seedling phase, and that from there, the source of energy for the maintenance of growth becomes the carbohydrates from photosynthesis.

The root and shoot biomass production decreased due to the presence of shading, a similar occurrence was reported by YANG et al. (2014) and YANG et al. (2017), who observed a reduction of the total soybean root biomass when they were submitted to intercropping with maize, due to the reduction in the quantity and the quality of the radiation. However, the authors reported that as there was an increase in crop spacing between rows of corn and soybeans, the negative effect of root biomass reduction was reduced due to better light penetration in the canopy.

Cotton is a perennial specie cultivated annually and according to McMICHAEL et al. (2010), the increase in the length of the cotton root

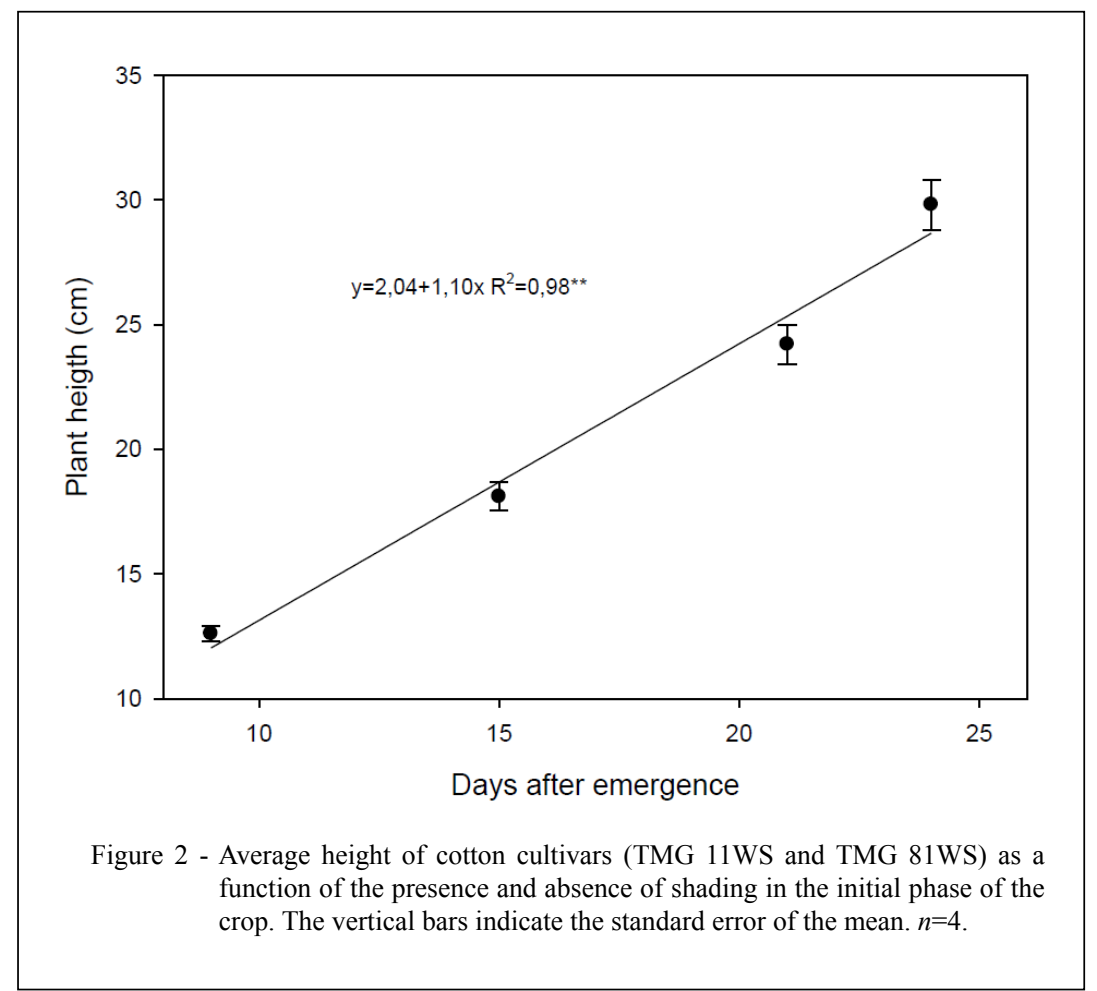

Ciência Rural, v.49, n.1, 2019. 
Table 2 - Cotton root characteristics as a function of shading and cultivar $(\mathrm{L}=$ root length, $\mathrm{S}=$ root surface, $\mathrm{AD}=$ mean diameter, $\mathrm{LV}=$ length by volume and RV = root volume).

\begin{tabular}{|c|c|c|c|c|c|c|}
\hline \multirow[b]{2}{*}{ Shading } & \multirow[b]{2}{*}{$\begin{array}{c}\text { Root/Shoot } \\
\text { ratio }\end{array}$} & $\mathrm{L}$ & S & $\mathrm{AD}$ & LV & RV \\
\hline & & $\mathrm{m}$ & $\mathrm{cm}^{-2}$ & $\mathrm{~mm}$ & $\mathrm{~km} \mathrm{~m}^{-3}$ & $\mathrm{~cm}^{-3}$ \\
\hline Shaded & 0.050 & $18.1 \mathrm{~b}$ & $288 b$ & $0.49 \mathrm{~b}$ & $60.3 \mathrm{~b}$ & $0.36 \mathrm{~b}$ \\
\hline Non-shaded & 0.081 & $45.6 \mathrm{a}$ & $811 \mathrm{a}$ & $0.58 \mathrm{a}$ & $152.2 \mathrm{a}$ & $1.17 \mathrm{a}$ \\
\hline --------------- & -----" & ----- & ultivar (C & ------. & ------- & ------- \\
\hline Late & 0.069 & 33.5 & 578 & 0.536 & 111.7 & 0.804 \\
\hline Early & 0.062 & 30.2 & 520 & 0.547 & 100.8 & 0.734 \\
\hline F Shade & $5.045^{\mathrm{ns}}$ & $15.10^{*}$ & $20.237^{*}$ & $10.52^{*}$ & $15.102^{*}$ & $22.14^{*}$ \\
\hline F Cultivar & $0.17^{\mathrm{ns}}$ & $0.13^{\text {ns }}$ & $0.132^{\mathrm{ns}}$ & $0.224^{\mathrm{ns}}$ & $0.132^{\mathrm{ns}}$ & $0.085^{\mathrm{ns}}$ \\
\hline F SxC & $0.13^{\text {ns }}$ & $0.06^{\mathrm{ns}}$ & $0.005^{\mathrm{ns}}$ & $1.703^{\mathrm{ns}}$ & $0.007^{\mathrm{ns}}$ & $0.011^{\mathrm{ns}}$ \\
\hline $\mathrm{CV}(\%)$ & 30.52 & 36.18 & 32.14 & 13.59 & 35.88 & 38.29 \\
\hline
\end{tabular}

${ }^{*} p<0.05$ and ns - non-significant $(\mathrm{p}>0.05) . \mathrm{n}=4$.

system continues until the first bolls are formed (which occurs at 50-65 DAE or 700 degrees day). At this time, although new root formation is occurring, there is a decline in total root length due to the death of old roots. Considering that in the present experiment the plants were cultivated until 27 DAE, in theory there would be a period of little more than 30 days for the root system to complete its growth before the formation of the first fruits. In other species, VALIO et al. (2001) observed that root growth of the tree species Trema micrantha was negatively affected by shading, but the seedlings tolerated low light for several months without severe damage. However, PAN et

Table 3 - Root length (L) of cotton by diameter class as a function of shading and cultivar.

\begin{tabular}{|c|c|c|c|c|}
\hline \multirow{3}{*}{ Shading (S) } & \multicolumn{4}{|c|}{ 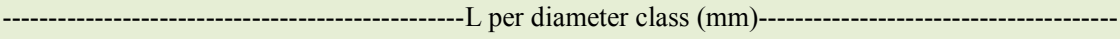 } \\
\hline & $0-0.5$ & $0.5-2.0$ & $2.0-5.0$ & $5.0-10.0$ \\
\hline & \multicolumn{4}{|c|}{ - } \\
\hline Shaded & $13.5 \mathrm{~b}$ & $4.1 \mathrm{~b}$ & $0.38 \mathrm{~b}$ & $0.009 \mathrm{~b}$ \\
\hline Non-shaded & $32.1 \mathrm{a}$ & $12.4 \mathrm{a}$ & $0.86 \mathrm{a}$ & $0.238 \mathrm{a}$ \\
\hline \multicolumn{5}{|l|}{ Cultivar (C) } \\
\hline Late & 23.5 & 9.13 & 0.69 & 0.09 \\
\hline Early & 22.1 & 7.41 & 0.55 & 0.15 \\
\hline F Shading & $10.87^{*}$ & $26.2^{*}$ & $8.709^{*}$ & $16.0^{*}$ \\
\hline F Cultivar & $0.05^{\mathrm{ns}}$ & $0.52^{\mathrm{ns}}$ & $0.63^{\mathrm{ns}}$ & $1.27^{\mathrm{ns}}$ \\
\hline F SxC & $0.008^{\text {ns }}$ & $0.008^{\mathrm{ns}}$ & $0.43^{\mathrm{ns}}$ & $0.46^{\mathrm{ns}}$ \\
\hline $\mathrm{CV}(\%)$ & 21.66 & 27.45 & 55.65 & 31.65 \\
\hline
\end{tabular}

${ }^{*} p<0.05$ and $\mathrm{ns}$ - non-significant. $\mathrm{n}=4$. 


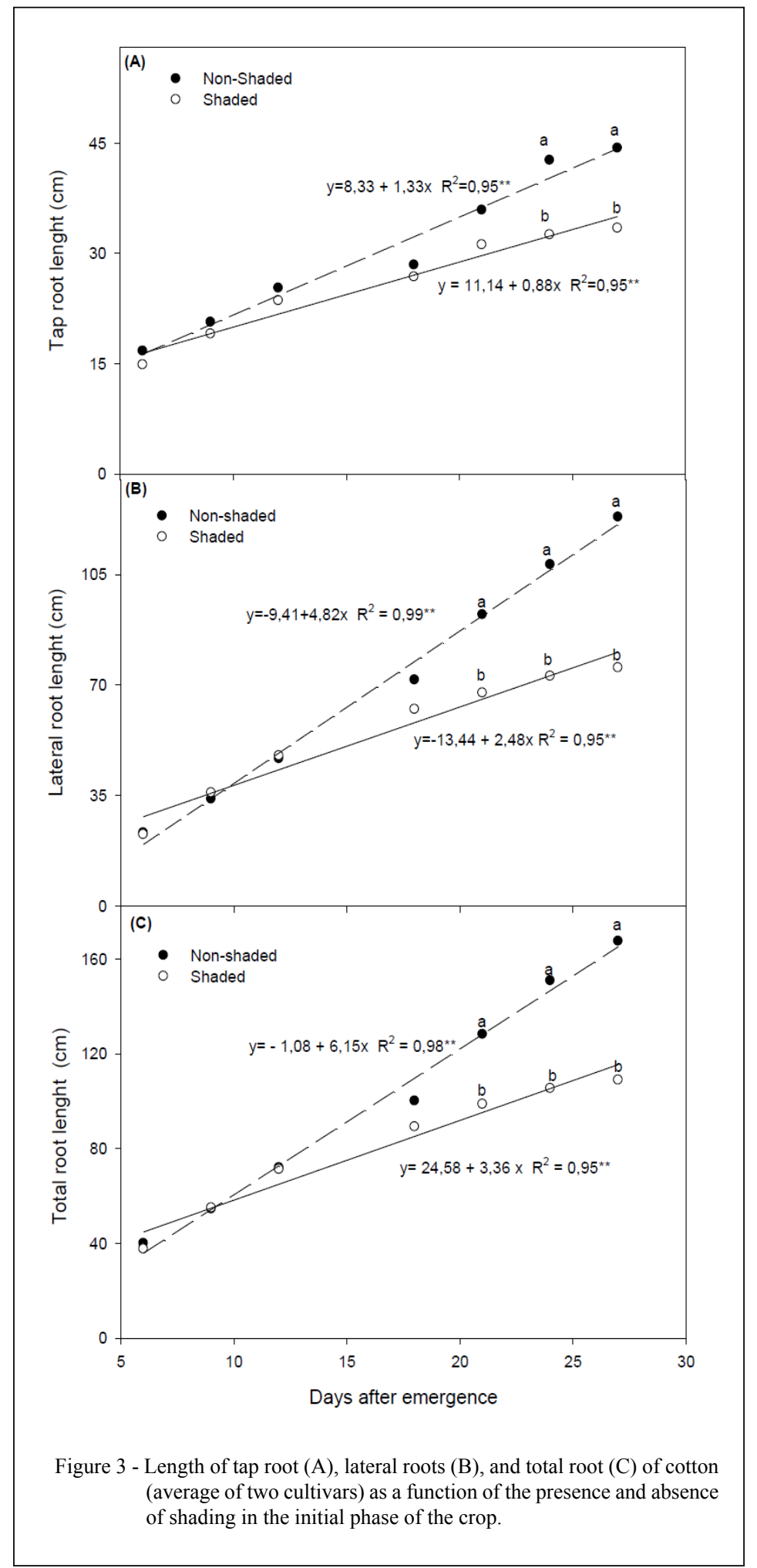

Ciência Rural, v.49, n.1, 2019. 
Table 4 - Root and shoot dry weight and carbohydrates partitioning on cotton as a function of shading and cultivar.

\begin{tabular}{|c|c|c|c|c|c|c|}
\hline \multirow{3}{*}{ Shading (S) } & \multicolumn{2}{|c|}{-------------Dry weight---------- } & \multicolumn{2}{|c|}{-------Carbohydrate content------ } & \multicolumn{2}{|c|}{-------Carbohydrate accumulation------ } \\
\hline & Root & Shoot & Root & Shoot & Root & Shoot \\
\hline & \multicolumn{2}{|c|}{------------g plant ${ }^{-1}$-------------. } & \multicolumn{2}{|c|}{------------mg g ${ }^{-1}$ DW----------- } & \multicolumn{2}{|c|}{-----------------mg plant ${ }^{-1}$----------------- } \\
\hline Shaded & $0.04 \mathrm{~b}$ & $1.01 \mathrm{~b}$ & 6.47 & $29.64 \mathrm{~b}$ & $0.33 \mathrm{~b}$ & $33.81 \mathrm{~b}$ \\
\hline Non-shaded & $0.24 \mathrm{a}$ & $2.81 \mathrm{a}$ & 5.05 & $46.51 \mathrm{a}$ & $1.51 \mathrm{a}$ & $128.32 \mathrm{a}$ \\
\hline \multicolumn{7}{|l|}{ Cultivar (C) } \\
\hline Late & 0.14 & 1.75 & 5.47 & 38.04 & 0.83 & 75.26 \\
\hline Early & 0.15 & 2.08 & 6.04 & 38.11 & 1.00 & 86.88 \\
\hline F (Shading) & $16.625^{* *}$ & $51.13^{*}$ & $1.853^{\mathrm{ns}}$ & $24.81^{* *}$ & $31.36^{* *}$ & $74.56^{* *}$ \\
\hline F (Cultivar) & $0.008^{\mathrm{ns}}$ & $1.290^{\mathrm{ns}}$ & $0.297^{\mathrm{ns}}$ & $0.000^{\mathrm{ns}}$ & $0.625^{\mathrm{ns}}$ & $1.11^{\mathrm{ns}}$ \\
\hline$F(\mathrm{SxC})$ & $0.054^{\mathrm{ns}}$ & $0.000^{\mathrm{ns}}$ & $0.004^{\mathrm{ns}}$ & $0.000^{\mathrm{ns}}$ & $0.734^{\mathrm{ns}}$ & $0.23^{\mathrm{ns}}$ \\
\hline CV $(\%)$ & 25.50 & 30.20 & 40.30 & 19.90 & 29.80 & 30.19 \\
\hline
\end{tabular}

${ }^{*} p<0.05$ and $\mathrm{ns}-$ non-significant. $\mathrm{n}=4$.

al. (2016) observed that the reductions of root growth, mean diameter and volume of the rice root subjected to shading in the panicle emission phase resulted in lower nutrient accumulation and lower yield.

Therefore, the effect of shading when it occurs in the early cotton phase may be more detrimental to the plant than in the flowering stage, particularly in places where the growing season is short, as water and nutrient absorption may be limited, especially in the period of fruit filling (BAL et al., 2016). The potential amount of water absorbed by a given crop will influence its growth rate when water becomes limited. In this situation, given the specific conditions of each soil, the water absorption will depend on the architecture of the root system (HAMMER et al., 2009). Thus, the smaller spatial arrangement of the roots causes a reduction in the size of the canopy, and consequently of the light interception area, which will limit the photosynthetic production of carbohydrates and the accumulation of biomass.

Other factors that also affect root growth should be considered, since they occur in an integrated way in the field, as observed by ALAMEDA et al. (2012) in tobacco, as reported that light reduction $(90 \%)$ reduced the root length of tobacco plants. However, when the soil was compacted, shading did not show any effects, indicating that the effects are complementary and additive. Thus, the effect of shading can often be superimposed by the effect of soil compaction or even other factors that inhibit root growth, such as nematode infection (DAVIS et al., 2014).

In this study we hypothesized that the cultivars could present different behaviors in relation to shading, but this was not confirmed for the tested cotton genotypes (TMG 81WS and TMG $11 \mathrm{WS})$. Contrary to what has been observed, PAN et al. (2016) observed that rice cultivars subjected to shading had different root growth, but only when cultivated under high nitrogen levels $\left(180 \mathrm{~kg} \mathrm{ha}^{-1}\right)$. In this way, genotypic differences in relation to low light availability would be pronounced only under higher $\mathrm{N}$ availability, because under low luminous intensity nitrate absorption $\left(\mathrm{NO}_{-3}\right.$ ) is lower ( $\mathrm{SINGH}$ \& SAWHNEY, 1989) and dependent on the continuous flow of soluble aerial part carbohydrates (RAPER et al., 1978). Consequently, plants that are growing under low light conditions and producing few carbohydrates (as observed in the present experiment) will have limited nitrate uptake, which may justify the similar responses of the studied genotypes to shading (Tables 1, 2 and 3).

\section{CONCLUSION}

Shading reduces dry matter accumulation and root growth in the early stages of cotton 
development, due to the lower content, and accumulation of carbohydrates in the plant shoot, and this response is not dependent on the cultivar.

\section{DECLARATION OF CONFLICTING INTERESTS}

We have no conflict of interest to declare.

\section{REFERENCES}

ALAMEDA, D. et al. Soil compaction effects on growth and root traits of tobacco depend on light, water regime and mechanical stress. Soil and Tillage Research, v.120, p.121129, 2012. Available: <https://www.sciencedirect.com/science/ article/pii/S0167198711002121>. Accessed: Apr. 26, 2018. doi: 10.1016/j.still.2011.11.013.

BAI, Z. et al. Study on light interception and biomass production of different cotton cultivars. PloS One, v.11, p.e0156335, 2016. Available: $<$ https://journals.plos.org/plosone/article?id=10.1371/ journal.pone.0156335>. Accessed: Apr. 28, 2018. doi: 10.1371/ journal.pone. 0156335 .

BRAND, D. et al. Interactive effects of carbon dioxide, low temperature, and ultraviolet-B radiation on cotton seedling root and shoot morphology and growth. Frontiers in Plant Science, v.10, p.607-620, 2016. Available: $<$ https://ink.springer.com/article/10.1007/s11707-0160605-0>. Accessed: Apr. 24, 2018. doi: 10.1007/s11707-016-0605-0.

DAVIS, R.F. et al. Effect of simultaneous water deficit stress and Meloidogyne incognita infection on cotton yield and fiber quality. Journal of Nematology, v.46, p.108-118, 2014. Available: $<$ https://www.ncbi.nlm.nih.gov/pmc/articles/PMC4077171/>. Accessed: Apr. 25, 2018.

DUBOIS, M. et al. Colorimetric method for determination of sugars and related substances. Analytical Chemistry, v.28, p.350356, 1956. Available: <https://pubs.acs.org/doi/pdf/10.1021/ ac60111a017>. Accessed: Apr. 24, 2018. doi: 10.1021/ac60111a017.

ECHER, F.R.; ROSOLEM, C.A. Cotton yield and fiber quality affected by row spacing and shading at different growth stages. European Journal of Agronomy, v.65, p.18-26, 2015. Available: $<$ https://www.sciencedirect.com/science/article/abs/pii/ S1161030115000027>. Accessed: Apr. 28, 2018. doi: 10.1016/j. eja.2015.01.001.

FERREIRA,D.F. Sisvar: a computer statistical analysis system. Ciencia e Agrotecnologia, v.35, p.1039-1042, 2011. Available: <http://www. scielo.br/scielo.php?pid=S1413-70542011000600001\&script $=$ sci arttext\&tlng=pt $>$. Accessed: Apr. 26, 2018. doi: 10.1590/S141370542011000600001 .

HANLEY, M. et al. Early plant growth: identifying the end point of the seedling phase. New Phytologist, v.163, p.61-66, 2004. Available: <https://nph.onlinelibrary.wiley.com/doi/full/ 10.1111/j.1469-8137.2004.01094.x>. Accessed: May 05, 2018. doi: 10.1111/j.1469-8137.2004.01094.x.

HUBER, S.C. Relation between photosynthetic starch formation and dry weight partitioning between the shoot and root. Canadian
Journal of Botany, v.61, p.2709-2716, 1983. Available: <http:// www.nrcresearchpress.com/doi/abs/10.1139/b83-298>. Accessed: Apr. 30, 2018. doi: 10.1139/b83-298.

LEE, H.J. et al. Multiple routes of light signaling during root photomorphogenesis. Trends in Plant Science, v.22, p.803-812, 2017. Available: $<$ https://www.sciencedirect.com/science/article/pii/ S1360138517301322>. Accessed: May 05, 2018. doi: 10.1016/j. tplants.2017.06.009.

McMICHAEL, B.L. et al. Growth and development of root systems. In: STEWART, J.M.; OOSTERHUIS, D.M.; HEITHOLT, J.; MAUNEY, J.R. (Ed.). Physiology of Cotton. Springer, New York, NY, USA. 2010. p.57-71.

PAN, S. et al. Effects of nitrogen and shading on root morphologies, nutrient accumulation, and photosynthetic parameters in different rice genotypes. Scientific Reports, v.6, p.32148, 2016. Available: $<$ https://www.nature.com/articles/srep32148>. Accessed: May 10, 2018. doi: 10.1038/srep32148.

RAPER, C.D.Jr. et al. Interdependence of root and shoot activities in determining nitrogen uptake rate of roots. Botanical Gazette, v.139, p.289-294, 1978. Available: <https://www.journals.uchicago.edu/ doi/abs/10.1086/337003>. Accessed: May 05, 2018.

SINGH, P.; SAWHNEY, S.K. Nitrate assimilation in plants. In: MEHTA, S.L.; LODHA, M.L.; SANE, P.V. (Ed.). Recent Advances in Plant Biochemistry. ICAR Publications, New Delhi, India, 1989. 141p.

TENNANT, D.A. A test of a modified line intersect method of estimating root length. Journal of Ecology, v.63, p.995-1001, 1975. Available: <https://www.jstor.org/ stable/2258617? casa token $=$ KG18SeVtdxUAAAAA:sInE0J sfejWDw5onSZUZ_JZVs-wtlfrAUG0bVtYxuOFCMdsHBY kBFrQTb6BMlwYwLGUcFjNmrLjA-rLjhrRkUb2pTgjnJPW eOXqlw3sK4zNB6w1Ym77zXA>. Accessed: Apr. 25, 2018. doi: $10.2307 / 2258617$.

VALIO, I.F.M. Effects of shading and removal of plant parts on growth of Trema micrantha seedlings. Tree Physiology, v.21, p.65-70, 2011. Available: <https://academic.oup.com/treephys/ article/21/1/65/1643173>. Accessed: Apr. 28, 2018. doi: 10.1093/ treephys/21.1.65.

YANG, F. et al. Growth of soybean seedlings in relay strip intercropping systems in relation to light quantity and red far-red ratio. Field and Crops Research, v.155, p.245-253, 2014. Available: <https:// www.sciencedirect.com/science/article/pii/S0378429013002815>. Accessed: May 05, 2018. doi: 10.1016/j.fcr.2013.08.011.

YANG, F. et al. Effect of aboveground and belowground interactions on the intercrop yields in maize-soybean relay intercropping systems. Field and Crops Research, v.203, p.16-23, 2017. Available: $<$ https:// www.sciencedirect.com/science/article/pii/S0378429016306736>. Accessed: May 10, 2018. doi: 10.1016/j.fcr.2016.12.007.

ZHAO, D.; OOSTERHUIS, D.M. Cotton responses to shade at different growth stages: nonstructural carbohydrate composition. Crop Science, v.38, p.1196-1203, 1998. Available: $<$ https://dl.sciencesocieties.org/publications/cs/abstracts/38/5/ CS0380051196>. Accessed: May 05, 2018. doi:10.2135/cropsci1 998.0011183X003800050014x. 